\title{
A Review of Microwave Assisted Liquefaction of Lignin in Hydrogen Donor Solvents: Effect of Solvents and Catalysts
}

\author{
Minghao Zhou ${ }^{1,2, *}$, Junming $X u^{1}$, Jianchun Jiang ${ }^{1}$ and Brajendra K. Sharma ${ }^{2, *(D)}$ \\ 1 Institute of Chemical Industry of Forest Products, Chinese Academy of Forestry (CAF), No.16, \\ Suojin Five Village, Nanjing 210042, China; xujunming@icifp.cn (J.X.); jiangjc@icifp.cn (J.J.) \\ 2 Illinois Sustainable Technology Center, Prairie Research Institute, One Hazelwood Dr. Champaign, \\ University of Illinois at Urbana-Champaign, Champaign, IL 61820, USA \\ * Correspondence: zmhzyk19871120@163.com (M.Z.); bksharma@illinois.edu (B.K.S.)
}

Received: 26 September 2018; Accepted: 18 October 2018; Published: 24 October 2018

\begin{abstract}
Lignin, a renewable source of aromatic chemicals in nature, has attracted increasing attention due to its structure and application prospect. Catalytic solvolysis has developed as a promising method for the production of value-added products from lignin. The liquefaction process is closely associated with heating methods, catalysts and solvents. Microwave assisted lignin liquefaction in hydrogen donor solvent with the presence of catalysts has been confirmed to be effective to promote the production of liquid fuels or fine chemicals. A great number of researchers should be greatly appreciated on account of their contributions on the progress of microwave technology in lignin liquefaction. In this study, microwave assisted liquefaction of lignin in a hydrogen donor solvent is extensively overviewed, concerning the effect of different solvents and catalysts. This review concludes that microwave assisted liquefaction is a promising technology for the valorization of lignin, which could reduce the reaction time, decrease the reaction temperature, and finally fulfill the utilization of lignin in a relatively mild condition. In the future, heterogeneous catalysts with high catalytic activity and stability need to be prepared to achieve the need for large-scale production of high-quality fuels and value-added chemicals from lignin.
\end{abstract}

Keywords: microwave; lignin; hydrogen donor solvent; catalysis; liquid fuels

\section{Introduction}

Biomass is regarded as one of the most promising renewable feedstocks for fossil energy, as it accounts for about $10 \%$ of the world's energy storage [1]. Biomass always consists of cellulose, hemicelluloses and lignin, which represents a large amount of renewable energy resource [2,3]; however, the application of biomass has not been fully exploited due to the difficulty of the conversion of lignin. Cellulose and hemicellulose can be converted into both biofuels and important platform chemicals (e.g., levulinic acid, furfural, etc.) [4,5]; therefore, lignin is left as an underutilized fraction. It is reported that most of the lignin source is burned for heat supply as a low value energy, while only about $2 \%$ of lignin is commercially used [6]. However, lignin is the most abundant and highly branched aromatic polymer in nature, which accounts for about $15-30 \%$ of different biomass feedstocks, consisting of a large amount of phenylpropane units (guaiacyl alcohol, syringyl alcohol, and $p$-coumaryl alcohol) $[7,8]$. The presence of phenylpropane units in lignin makes it a possible and promising alternative for the production of liquid fuels and/or aromatic compounds (such as vanillin, guaiacol, syringaldehyde, etc.) [9]. Therefore, it remains a great challenge to develop effective technologies for the liquefaction and utilization of lignin to liquid fuels and aromatic compounds, as lignin is the 
most abundant and important renewable source in nature [10-13]. In recent decades, varied strategies have been explored for the utilization and valorization of lignin, including gasification, pyrolysis and liquefaction [14-19]. Among those conversion methods, lignin liquefaction with microwave heating has exhibited to be effective for the conversion of lignin in mild conditions, which is of better energy efficiency and higher selectivity.

It is reported that solvents and catalysts are the main factors influencing the liquefaction efficiency and product distributions during the lignin liquefaction process [20-24], and researchers have achieved significant progress using suitable solvents and catalysts, coupled with microwave heating technology [20-24]. Microwave heating technology has been widely applied in lignin liquefaction and exhibited to be a promising technology due to its advantage, in comparison with a conventional heating method [25-27]. Solvents and catalysts played important roles during the microwave assisted liquefaction of lignin [28-31]. Polar solvents, which were proper microwave receptors, were previously regarded to be effective during the lignin depolymerization, coupled with suitable catalysts and microwave heating [31-33]. Zhang et al. reported that lignin structure had a great effect on the lignin degradation with $\mathrm{CrCl}_{3}$ and $\mathrm{Pd} / \mathrm{C}$ as catalysts in methanol [28]. Luque et al. reported the promotion effect of $\mathrm{NiO} / \mathrm{HZSM}-5$ during the microwave assisted depolymerization of bio lignin, eucalyptus, and hardwood lignin to give bio-oil, indicating that bio-oil yield was also associated with lignin feedstock [24]. This review focuses on presenting recent developments in microwave assisted liquefaction of lignin for renewable fuels and value-added chemicals, with the help of different types of solvents and catalysts.

\section{Chemical Structure of Lignin}

Lignin is a natural phenolic polymer, containing three types of phenylpropane monomer units, namely, $p$-hydroxyphenyl $(\mathrm{H})$, guaiacyl $(\mathrm{G})$ and syringyl (S) units linked by $\mathrm{C}-\mathrm{O}$ or $\mathrm{C}-\mathrm{C}$ bonds. The proportion of these linkages and specific functional groups are highly dependent on the lignin sources and isolation/extraction methods [34]. The linkages between phenylpropane units in the lignin structure mainly include C-O bonds (e.g., $\beta-\mathrm{O}-4, \alpha-\mathrm{O}-4$, and $4-\mathrm{O}-5$, etc.) and C-C bonds ( $\beta-1, \beta-5$, $5-5^{\prime}$, etc.). It was estimated that $\mathrm{C}-\mathrm{O}$ bonds accounted for more than two-thirds of the total linkages in native lignin, apart from other $\mathrm{C}-\mathrm{C}$ bonds $[1,35]$. Therefore, the effective cleavage of $\mathrm{C}-\mathrm{O}$ bonds and $\mathrm{C}-\mathrm{C}$ bonds is the key during the lignin liquefaction process.

Lignin is always left after the utilization of cellulose and hemicelluloses, or isolated for valorization. Therefore, lignin obtained from different processes would possess different chemical structures. For example, lignins from different sources exhibited certain differences in nature, such as average molecular weight, solubility in solvents, functional groups, etc. Generally, lignin could be divided into the following groups based on the separation/extraction process [36-39], including kraft lignin, organosolv lignin, lignosulfonated lignin, pyrolytic lignin, steam explosion lignin and acidolysis lignin.

Kraft lignin was mainly obtained from kraft pulping process, and the general percentage of lignin in the black liquor from kraft pulping usually ranged from $29-45 \%$ for cook of paper grade and $8-16 \%$ for cook of liner grade [37]. Kraft lignin was always soluble in alkali solution and some high polar organic solvents. Organosolv lignin was usually generated from organosolv pulping process, which was soluble in organic solvents, with improved purity, increased phenolic hydroxyl groups and much lower sulfur content [37]. In comparison with kraft lignin, organosolv lignin reserved much better original structure in forms of original inter-unit linkages through $\beta-\mathrm{O}-4$ or some other linkages. Thus, organosolv lignin was one kind proper lignin source for future lignin valorization to either liquid fuels or fine chemicals. Among the six different types of lignin, kraft lignin and organosolv lignin were reported to have a great potential for the production of value-added chemicals [39]. As it is rather difficult to take different kinds of lignin sources into consideration, so, herein, the effect of different lignin sources was not included in this review. 


\section{Microwave Assisted Lignin Liquefaction in Hydrogen Donor Solvents}

Catalytic solvolysis of lignin with microwave heating has been widely regarded as an effective technology for the conversion and utilization of lignin. Microwave assisted lignin liquefaction processes include the cleavage of $\mathrm{C}-\mathrm{O}, \mathrm{C}-\mathrm{C}$ bonds, and hydrogenation/hydrodeoxygenation reaction. Liquid fuel and aromatic phenolics are the main products from the microwave assisted liquefaction of lignin over different kinds of catalysts. In this section, the effects of different solvents and catalystson the production of liquid fuel and/or fine chemicals from the microwave assisted liquefaction of lignin will be discussed. A general summary of research on the microwave assisted liquefaction of different lignin feedstocks (kraft lignin, organsolv lignin, etc.) was presented in Table 1.

\subsection{Effect of Solvents}

Hydrogen donor solvents have been reported effective for the lignin liquefaction under mild reaction conditions, coupled with microwave heating. In recent literature, both single component and multi-component types of hydrogen donor solvents were used during the microwave assisted liquefaction process for lignin valorization, with or without the presence of catalysts $[19,22-24,40-43]$.

\subsubsection{Hydrogen Donor Solvent of Single Components}

In recent literature, formic acid and some alcohols (methanol, ethanol, etc.) were widely considered as promising single component hydrogen donor solvent and microwave receptors during the microwave assisted lignin liquefaction.

Liu et al. comparatively explored alcohols assisted liquefaction of lignin under microwave heating, finding that methanol and ethanol exhibited to be much more suitable to convert lignin to liquefied products [19]. Alcohol solvents had great effect on the product distributions in the liquid products, and the residual solid also exhibited to be of great difference in micro-structure morphology after depolymerization. The lignin conversion rates were as high as $84.86 \%$ and $84.22 \%$ in methanol and ethanol, respectively, when compared with butanol, ethanediol and isopropanol. In addition, microwave assisted lignin liquefaction in methanol or ethanol could induce much lower molecular weights for liquefied products, and more C-O-C cleavage of lignin, in comparison with other alcohols.

Luque et al. studied a series of hydrogen donor solvents (including tetralin, glycerol, formic acid and isopropanol) in the depolymerization of lignin obtained from olive tree pruning waste using a microwave assisted approach [42]. It was observed that the phenolic monomeric products were highly dependent on the type of hydrogen donor solvent, while the highest lignin conversion rate was obtained in formic acid without the formation of biochar, in comparison with other hydrogen donor solvents. The application of formic acid, combined with microwave heating and Ni-based catalyst, could provide promising quantities of phenolic monomeric compounds, such as syringol, syringaldehyde and vanillin. The liquefaction process in formic acid could also produce larger quantities of syringyl than guaiacyl derivatives. In the future study, Luque et al. further investigated the microwave assisted liquefaction of different types of lignin (biolignin, eucalyptus, and hardwood lignins) to simple aromatics with formic acid as hydrogen donor solvent. It was found that the yields of liquid bio-oil and the compositions were closely associated with the lignin structures, and most of the monomeric aromatics were syringyl derived chemicals with varied proportions in bio-oil [24]. Luque et al.'s research has proposed promising methodologies for the further development of the lignin valorization to value-added aromatics.

Shen et al. investigated the microwave assisted lignin liquefaction in isopropanol without catalysts, studying the effect of reaction temperature and reaction time on the yield of liquid product, residual lignin and char [43]. The highest bio-oil yield was up to $45.35 \%$ at mild reaction conditions $\left(120{ }^{\circ} \mathrm{C}, 30 \mathrm{~min}\right.$ ), with the yield of char and residual lignin of $38.65 \%$ and $14.73 \%$, respectively. The aromatic compounds in liquid product (both monomers and oligomers) were identified, finding that ethanone, 1-(4-hydroxy-3-methoxyphenyl) and ethanone, 1-(4-hydroxy-3,5-dimethoxy phenyl) 
were the prominent aromatic monomers in the liquid product. Fragments from the aromatic oligomers detected were mainly located from $248 \mathrm{~m} / z$ to $496 \mathrm{~m} / z$. The aromatic oligomers with the molecular weight of $274 \mathrm{~m} / z, 290 \mathrm{~m} / z, 316 \mathrm{~m} / z, 332 \mathrm{~m} / z, 362 \mathrm{~m} / z, 406 \mathrm{~m} / z, 454 \mathrm{~m} / z$ were detected by Matrix Assisted Laser Desorption-Ionisation Time of-Flight Mass Spectrometry (MALDI-TOF MS), thus a possible lignin depolymerization pathway was proposed according to the monomers and oligomers distributions, in order to understand the relationship with the formation of prominent monomers. The cleavage of $\mathrm{C}_{\beta}$-O bond in lignin first happened, and then the cracking of $\mathrm{C}_{\gamma}-\mathrm{O}$ and $\mathrm{C}_{\beta}-\mathrm{C} \gamma$ bond happened, finally $\mathrm{C}_{\alpha}-\mathrm{O}$ cracking took place to give vanillin and ethanone, 1-(4-hydroxy-3-methoxyphenyl), which was reported to be substantially promoted by the acidity of HUSY zeolite catalysts [23].

Xiao et al. reported the microwave assisted liquefaction of lignin in formic acid, with the addition of modified HUSY catalysts during the depolymerization system [23]. The highest yield of liquid product was about $88.28 \%$, containing $15.36 \%$ of aromatic monomers and $67.52 \%$ of oligomer fractions, while the liquefaction was conducted in a microwave reactor in a fixed reaction condition (power: $600 \mathrm{~W}$, reaction temperature: $130{ }^{\circ} \mathrm{C}$, reaction time: $30 \mathrm{~min}$ ). Aromatic oligomers with molecular weight of $328,342,358,378,394,424$ and 454 were detected by MALDI-TOF MS, which was a little different with Shen's research results [43]. Shen et al. reported that the highest yield of liquid product was $45.35 \%$ achieved at $120{ }^{\circ} \mathrm{C}$ with a reaction time of $30 \mathrm{~min}$, together with a yield of char as $38.65 \%$ [43].

Labidi et al. investigated the microwave assisted depolymerization of lignin to some simple aromatics in tetralin and formic acid, aiming to obtain the maximum bio-oil yield and the phenolic monomers content [22]. It was interesting to find that most of those phenolic products were solvent derived products, such as diethyl phthalate and butyl-octyl phthalate ester. In addition, some other phenolic chemicals, such as mesitol and syringaldehyde, were also observed, which was highly dependent on the solvents used in the liquefaction system. The obtained bio-oil consisted of phenolic monomers and oligomers, and it was also confirmed that formic acid could help to decrease the formation of biochar compared with tetralin, while the yield of biochar was much higher in most cases (up to 35\%) due to existing oligomerization reactions except for the case of the application of formic acid. This might be ascribed to the decomposition of formic acid into gases (e.g., $\mathrm{CO}, \mathrm{CO}_{2}$ and $\mathrm{H}_{2}$ ) during the lignin depolymerization, while other hydrogen donor solvents (such as tetralin) would react with those unstable fragments and/or radicals to form biochar. A similar phenomenon was also observed in other studies [23,42,43], indicating that formic acid could lead to the decrease of bio-char.

$\mathrm{Xu}$ et al. investigated the microwave assisted liquefaction of alkaline lignin in methanol, and compared the effect of microwave heating and electric heating [41]. The promotional effect of microwave heating was confirmed, as higher bio-oil yield could be obtained at relative mild reaction conditions. The highest yield of bio-oil was up to $60.1 \%$, when the depolymerization was conducted at $160{ }^{\circ} \mathrm{C}$ for $80 \mathrm{~min}$. $p$-hydroxyacetophenone, guaiacol, $p$-hydroxyacetovanillon and syringaldehyde were detected as main monophenols in bio-oil. In addition, possible chemical structures for oligomers with molecular weight of $288 \mathrm{~m} / z, 306 \mathrm{~m} / \mathrm{z}, 316 \mathrm{~m} / \mathrm{z}, 330 \mathrm{~m} / \mathrm{z}, 412 \mathrm{~m} / \mathrm{z}, 426 \mathrm{~m} / \mathrm{z}, 456 \mathrm{~m} / \mathrm{z}$ were observed. Finally, plausible depolymerization pathways were proposed in order to facilitate the understanding of possible relationship for the formation of prominent oligomers and monomers.

Vinu et al. investigated the microwave assisted degradation of lignin in the presence of different organic solvents (including ethylene glycol, dimethyl sulfoxide, dimethyl formamide) under relatively mild reaction conditions (temperature between $100-140{ }^{\circ} \mathrm{C}$, time between $20-80 \mathrm{~min}$ ) [44]. An obvious reduction in average molecular weight $\left(\mathrm{M}_{\mathrm{w}}\right)$ of lignin was observed in all the solvents, and it was found that the $\mathrm{M}_{\mathrm{w}}$ reduction was highly dependent on the solvent polarity and temperature. In polar protic solvent, like ethylene glycol, maximum reduction in $\mathrm{M}_{\mathrm{W}}$ was observed at $120^{\circ} \mathrm{C}$; in polar aprotic solvents, like dimethyl sulfoxide and dimethyl sulfoxide, $\mathrm{M}_{\mathrm{W}}$ decreased with the increase of reaction temperature. Ethylene glycol, dimethyl sulfoxide, dimethyl formamide gave similar decrease in $\mathrm{M}_{\mathrm{w}}$ at lower temperature (e.g., $\left.100{ }^{\circ} \mathrm{C}\right)$, and at relatively higher temperature $\left(120\right.$ or $\left.140{ }^{\circ} \mathrm{C}\right)$, the microwave absorbing ability and polarity greatly affected the decrease of $\mathrm{M}_{\mathrm{W}}$. While the maximum reduction 
of $\mathrm{M}_{\mathrm{w}}$ in ethylene glycol and dimethyl sulfoxide was both observed at $120^{\circ} \mathrm{C}$, and the maximum degradation of lignin in dimethyl formamide was observed at $140^{\circ} \mathrm{C}$. Then, plausible pathways for the cleavages of $\mathrm{C}_{\beta}-\mathrm{O}$ and $\mathrm{C}_{\alpha}-\mathrm{C}_{\beta}$ during the formation of phenolic monomers and dimers were discussed considering the solvent interactions. Solvents were found to have great effect on the lignin depolymerization: in ethylene glycol, the cleavage of $C_{\beta}-O$ bond was preferred over $C_{\alpha}-C_{\beta}$ bond, and the cleavage of $\mathrm{C}_{\beta}$-O ether linkage could lead to the formation of guaiacol; in dimethyl sulfoxide, anisole, guaiacol, syringaldehyde and acetosyringone were generated after the cleavage of both $\mathrm{C}_{\beta}-\mathrm{O}$ and $\mathrm{C}_{\alpha}-\mathrm{C}_{\beta}$ bond; in dimethyl formamide, solvent was protonated by $\mathrm{H}^{+}$ions produced from the lignin demethoxylation, then syringaldehyde could be generated in a significant amount through the $\mathrm{C}_{\alpha}-\mathrm{C}_{\beta}$ cleavage.

\subsubsection{Hydrogen Donor Solvent of Multi-Component}

Apart from single component solvent, hydrogen donor solvents of multi-component have also been widely investigated because of their high lignin liquefaction efficiency. $\mathrm{Xu}$ et al. investigated the microwave assisted liquefaction of alkaline lignin in methanol-formic acid media, studying the effect of mixed solvent composition and reaction parameters on the product distributions [45]. The introduction of formic acid into methanol helped to improve the liquefaction of lignin under microwave heating system, as formic acid could act through acid-catalyzed cleavage of the linkages in lignin. The highest bio-oil yield was up to $72.0 \%$, including $6.7 \%$ monomers, achieved under mild reaction conditions $\left(160{ }^{\circ} \mathrm{C}, 30 \mathrm{~min}\right.$, formic acid to lignin ratio of 4). 2,3-dihydrobenzofuran and $p$-coumaric acid were detected as the main monomers, and oligomers in the liquid products mainly contained dimers (molecular weight of 253-378) and trimers (molecular weight of 379-510). Therefore, $\mathrm{Xu}$ et al. also proposed a possible mechanism for microwave assisted degradation of lignin in methanol-formic acid media, based on the monomers and oligomers detected in the liquefied products. It was found that the cleavage of the $\mathrm{C}_{\beta}$-O bond was the first step because of the lowest bond dissociation energy, giving two kinds of C-9 monomeric free radicals. Then, some guaiacol-type and syringol-type compounds could be produced from those two monomeric radicals through either $\mathrm{C}_{\alpha}-\mathrm{C}_{\beta}$ cracking or $\mathrm{C}_{\alpha} \mathrm{O}-\mathrm{H}$ cracking.

Qiu et al. studied the liquefaction of wheat straw alkali lignin to obtain liquid bio-fuel under microwave heating in phenol-ethylene glycol [46]. They also compared the microwave assisted lignin liquefaction efficiency with a traditional thermal liquefaction process, finding that microwave heating could help to improve the monophenolic compounds yield in liquefied product. An extra $29 \%$ cleavage of $\mathrm{C}_{\text {aryl }}-\mathrm{C}_{\alpha}$ bond in lignin was observed under microwave heating, and the amount of monophenolic compounds improved from $0.92 \%$ to $13.61 \%$ under the same reaction conditions. The highest yield of monophenolic chemicals reached $15.77 \%$ under a mild liquefaction condition $\left(120^{\circ} \mathrm{C}, 40 \mathrm{~min}\right)$ in phenol-ethylene glycol.

Liu et al. further studied the microwave assisted organosolv lignin in ethanol-formic acid media [47], as they previously found that methanol and ethanol were much more suitable for the lignin liquefaction [19-21]. They found that the reaction temperature was much more influential during the lignin in ethanol-formic acid. The phenolic compounds amount in the liquid products increased from $8.1 \%$ to $40.8 \%$, when the temperature rose from 100 to $200{ }^{\circ} \mathrm{C}$. Additionally, the average molecular weight also decreased with the increased temperature during the lignin liquefaction process under microwave heating.

Piszczyk et al. investigated the conversion of lignin to biopolyols via microwave assisted liquefaction in crude glycerol and 1,4-butanediol at mild reaction conditions (temperature of $130-170{ }^{\circ} \mathrm{C}$ ) [48]. Finally, a polyol with a hydroxyl number of $670 \mathrm{mg} \mathrm{KOH} / \mathrm{g}$ was achieved with a yield of $93 \%$, and liquefied biopolyol could be directly used for the production of rigid polyurethane foams. The results indicated that microwave assisted liquefaction of lignin in glycerol and 1,4-butanediol could provide a good alternative to petroleum-derived materials.

Qiu and Ouyang et al. also explored the microwave assisted selective cleavage of $C_{\alpha}-C_{\beta}$ in mixed methanol and water $[49,50]$. They reported that the $C_{\alpha}-C_{\beta}$ bonds in phenolic and non-phenolic dimers 
could be selectively cleaved with microwave heating. The product distributions indicated that the determining step during the microwave assisted decomposition process was the formation of alkenyl products, although etherification reaction and the decomposition of alkenyl products also took place in relatively fast reaction steps.

In summary, hydrogen donor solvents, either single component or multi-component, exhibited to be promising in the microwave assisted lignin liquefaction system. The multi-function of hydrogen donor solvents should be further studied for effective liquefaction of lignin.

\subsection{Effect of Catalysts}

Catalysts were involved in most of the lignin liquefaction reactions in hydrogen donor solvents with microwave heating. The catalysts mostly used for the microwave assisted lignin liquefaction could be generally divided into homogeneous and heterogeneous catalysts $[20,21,26,46,49-56]$.

Table 1. Summary of microwave assisted liquefaction of lignin under different reaction conditions.

\begin{tabular}{|c|c|c|c|c|}
\hline Feedstock & Reaction Conditions & Catalysts & Products & Reference \\
\hline $\begin{array}{l}\text { Ethanol organsolv } \\
\text { lignin }\end{array}$ & $\begin{array}{c}\text { alcohols, } \mathrm{S} / \mathrm{L}=24: 1,100 \mathrm{~W} \\
160^{\circ} \mathrm{C}, 30 \mathrm{~min}\end{array}$ & $\mathrm{H}_{2} \mathrm{SO}_{4}$ & bio-oil, solid residual & [19] \\
\hline Lignin fromolive tree & $\begin{array}{l}\text { tetralin or formic acid, } \\
\mathrm{S} / \mathrm{L}=25: 1,400 \mathrm{~W}, 140^{\circ} \mathrm{C} \\
30 \mathrm{~min}\end{array}$ & $\mathrm{Ni} / \mathrm{Al}-\mathrm{SBA}$ & $\begin{array}{l}\text { guaiacol and syringol-type } \\
\text { compounds }\end{array}$ & [22] \\
\hline $\begin{array}{c}\text { Lignin fromblack } \\
\text { liquor }\end{array}$ & $\begin{array}{c}\text { formic acid, } 24: 1,600 \mathrm{~W}, \\
130^{\circ} \mathrm{C}, 30 \mathrm{~min}\end{array}$ & HUSY & $\begin{array}{l}\text { bio-oil (monophenol, } \\
\text { oligomer) }\end{array}$ & [23] \\
\hline $\begin{array}{l}\text { Biolignin, eucalyptus } \\
\text { and hardwood lignins }\end{array}$ & $\begin{array}{c}\text { formic acid, } \mathrm{S} / \mathrm{L}=24: 1,400 \mathrm{~W} \\
180^{\circ} \mathrm{C}, 60 \mathrm{~min}\end{array}$ & $\mathrm{NiO} / \mathrm{H}-\mathrm{ZSM}-5$ & $\begin{array}{l}\text { bio-oil (mesitol, banillin), } \\
\text { biochar }\end{array}$ & [24] \\
\hline Biochoice lignin & $\begin{array}{l}\text { dioxand-methtanol, } \\
\mathrm{S} / \mathrm{L}=30: 1,200-280^{\circ} \mathrm{C} \\
30-180 \mathrm{~min}\end{array}$ & $\mathrm{Ce} / \mathrm{CNT}, \mathrm{La} / \mathrm{CNT}$ & liquefied fuel, oligomers & [26] \\
\hline Biomass from China & $\begin{array}{l}\text { ethylene glycol, } \mathrm{S} / \mathrm{L}=18.5: 1, \\
130-170^{\circ} \mathrm{C}, 0-35 \mathrm{~min}\end{array}$ & $\mathrm{H}_{2} \mathrm{SO}_{4}$ & $\begin{array}{l}\text { bio-oil (fatty acid methyl } \\
\text { ester, alkane) }\end{array}$ & [29] \\
\hline Organosolv lignin & $\begin{array}{l}\text { water-sulfolane, } \mathrm{S} / \mathrm{L}=20: 1 \\
275^{\circ} \mathrm{C}, 30 \mathrm{~min}\end{array}$ & indium triflate & methylated liquid product & [31] \\
\hline Alkaline lignin & $\begin{array}{c}\text { methanol, } \mathrm{S} / \mathrm{L}=40: 1,400 \mathrm{~W} \\
100-160^{\circ} \mathrm{C}, 40-80 \mathrm{~min}\end{array}$ & CuNiAl & $\begin{array}{l}\text { bio-oil (monophenol, } \\
\text { oligomer) }\end{array}$ & [41] \\
\hline $\begin{array}{l}\text { Lignin from } \\
\text { agricultural residues }\end{array}$ & $\begin{array}{c}\text { tetralin, glycerol, formic acid } \\
\text { or isopropanol, } \mathrm{S} / \mathrm{L}=25: 1, \\
150^{\circ} \mathrm{C}, 30 \mathrm{~min}\end{array}$ & Ni/Al-SBA-15 & $\begin{array}{l}\text { bio-oil, biochar, residual } \\
\text { lignin }\end{array}$ & [42] \\
\hline $\begin{array}{l}\text { Lignin from black } \\
\text { liquor }\end{array}$ & $\begin{array}{c}\text { isopropanol, } \mathrm{S} / \mathrm{L}=16: 1, \\
600 \mathrm{~W}, 100-180{ }^{\circ} \mathrm{C}, 5-60 \mathrm{~min}\end{array}$ & / & bio-oil, char & [43] \\
\hline Alkaline lignin & $\begin{array}{l}\text { ethylene glycol, DMSO or } \\
\text { DMF, } \mathrm{S} / \mathrm{L}=50: 1,600 \mathrm{~W}, \\
100-140^{\circ} \mathrm{C}, 20-80 \mathrm{~min}\end{array}$ & / & $\begin{array}{l}\text { syringaldehyde, } \\
\text { acetosyringone, etc. }\end{array}$ & [44] \\
\hline Alkaline lignin & $\begin{array}{c}\text { methanol-formic acid, } \\
\mathrm{S} / \mathrm{L}=24: 1,400 \mathrm{~W}, 120-180^{\circ} \mathrm{C} \text {, } \\
15-45 \mathrm{~min}\end{array}$ & / & $\begin{array}{l}\text { bio-oil (monophenol, } \\
\text { oligomer), residue }\end{array}$ & [45] \\
\hline Alkaline lignin & $\begin{array}{c}\text { ethylene glycol-phenol, } \\
\mathrm{S} / \mathrm{L}=20: 1,300 \mathrm{~W}, 100-180^{\circ} \mathrm{C}, \\
10-60 \mathrm{~min}\end{array}$ & $\mathrm{H}_{2} \mathrm{SO}_{4}$ & guaiacols, syringols & [46] \\
\hline Bamboo lignin & $\begin{array}{c}\text { ethanol-formic acid, } \\
\mathrm{S} / \mathrm{L}=24: 1,80 \mathrm{~W}, 100-200{ }^{\circ} \mathrm{C} \\
20-60 \mathrm{~min}\end{array}$ & / & $\begin{array}{l}\text { bio-oil (guaiacol, vanillin, } \\
\text { syringol, etc.) }\end{array}$ & [47] \\
\hline Lignin (Sigma-Aldrich) & $\begin{array}{c}\text { glycerol, 1,4-butanediol, } \\
\mathrm{S} / \mathrm{L}=5: 1,180 \mathrm{~W}, 130-170{ }^{\circ} \mathrm{C}, \\
5 \mathrm{~min}\end{array}$ & / & biopolyols & [48] \\
\hline
\end{tabular}


Table 1. Cont.

\begin{tabular}{|c|c|c|c|c|}
\hline Feedstock & Reaction Conditions & Catalysts & Products & Reference \\
\hline $\begin{array}{l}\text { Lignin model } \\
\text { compounds }\end{array}$ & $\begin{array}{l}\text { methanol-water, } 400 \mathrm{~W}, \\
140,160^{\circ} \mathrm{C}, 2-60 \mathrm{~min}\end{array}$ & ferric sulfate & phenolic monomers & [49] \\
\hline Organosolv lignin & $\begin{array}{l}\text { methanol-water, } 160^{\circ} \mathrm{C}, \\
30 \mathrm{~min}\end{array}$ & ferric sulfate & $\begin{array}{l}\text { vanillin, syringaldehyde, } \\
\text { etc. }\end{array}$ & {$[50]$} \\
\hline Organosolv lignin & $\begin{array}{c}\text { PEG, glycerol, } \mathrm{S} / \mathrm{L}=85: 15, \\
155^{\circ} \mathrm{C}, 5 \mathrm{~min}\end{array}$ & $\mathrm{H}_{2} \mathrm{SO}_{4}$ & polyols & [55] \\
\hline Bamboo residues & $\begin{array}{c}\text { methanol, glycerol, } \mathrm{S} / \mathrm{L}=4: 1 \\
150^{\circ} \mathrm{C}, 3 \mathrm{~min}\end{array}$ & $\mathrm{H}_{2} \mathrm{SO}_{4}$ & bio-polyols & [56] \\
\hline Switchgrass & $\begin{array}{c}\text { methanol-glycerol, } \mathrm{S} / \mathrm{L}=4: 1, \\
155^{\circ} \mathrm{C}, 5 \mathrm{~min}\end{array}$ & $\mathrm{H}_{2} \mathrm{SO}_{4}$ & $\begin{array}{l}\text { mixtures for polyurethane } \\
\text { foams }\end{array}$ & [57] \\
\hline
\end{tabular}

$\mathrm{S} / \mathrm{L}$ means the solvent to lignin ratio. CNT: carbon nanotubes

\subsubsection{Homogeneous Catalyst}

Several studies reported the application of homogeneous catalysts in the microwave assisted lignin liquefaction in hydrogen donor solvents, which could be generally grouped into acid/base catalysts and/or metal salts. Liu et al. investigated the catalytic performance of different acids (including sulfuric acid, hydrochloric acid, formic acid, etc.) and metal chloride catalysts (e.g., $\mathrm{MgCl}_{2}$, $\mathrm{ZnCl}_{2}, \mathrm{AlCl}_{3}, \mathrm{FeCl}_{3}$, etc.) under microwave heating [20,21]. Sulfuric acid showed much better catalytic efficiency to convert lignin to liquid products than other acids used. Additionally, sulfuric acid could produce liquid products with much lower molecular weight than that of other acid catalysts during the depolymerization process because of its strong acidity [20]; the results were in good accordance with Qiu et al.'s study results [46]. Liu et al. also reported that the liquefied products compositions were closely dependent on the metal chloride catalysts used during the depolymerization process, inducing that the chloride' cation radius might have some effects on the catalytic performance of catalysts [21]. Among the five types of metal chloride catalysts $\left(\mathrm{MgCl}_{2}, \mathrm{ZnCl}_{2}, \mathrm{AlCl}_{3}, \mathrm{FeCl}_{3}\right.$, $\mathrm{MnCl}_{2}$ ), $\mathrm{MnCl}_{2}$ showed much higher catalytic ability to produce aromatic monomers from lignin. Liquid products contained about 23.0\% G-type, 11.9\% S-type and 14.8\% H-type monomer compounds catalyzed by $\mathrm{MnCl}_{2}$. Furthermore, the highest vanillin yield of $2.78 \%$ was obtained over $\mathrm{MnCl}_{2}$ under mild depolymerization condition.

Qiu et al. investigated the microwave assisted liquefaction of alkali lignin in phenol-ethylene glycol over $\mathrm{H}_{2} \mathrm{SO}_{4}$ and some solid catalysts $\left(\mathrm{Al}_{2}\left(\mathrm{SiO}_{4}\right)_{3}, \mathrm{Al}_{2} \mathrm{O}_{3}, \mathrm{FeS}\right)$ [46]. They found that catalyst with a strong acidity could promote the cleavage of aryl ether bond in lignin. Thus, $\mathrm{H}_{2} \mathrm{SO}_{4}$ showed much better liquefaction efficiency compared with solid catalysts used in the process, while $\mathrm{H}_{2} \mathrm{SO}_{4}$ possessed much stronger acidity than selected solid catalysts. The total yield of monophenolic compounds improved obviously to $15.77 \%$ under a relatively mild condition. Furthermore, it was confirmed that microwave heating could promote the cleavage of $\mathrm{C}_{\text {aryl }}-\mathrm{C}_{\alpha}$ bonds compared with conventional electrical heating, an extra $29 \% \mathrm{C}_{\text {aryl }}-\mathrm{C}_{\alpha}$ bonds cleavage was observed during the microwave assisted liquefaction. Labidi et al. reported that organosolv lignin could be liquefied under microwave heating at $155{ }^{\circ} \mathrm{C}$ in $5 \mathrm{~min}$ catalyzed by $\mathrm{H}_{2} \mathrm{SO}_{4}$ (solvent/lignin ratio of 85/15, $v / w$ ) [54]. The highest liquefaction yield was up to $99.07 \%$, while the hydroxyl number of the liquefied product could reach $811.8 \mathrm{mg} \mathrm{KOK} / \mathrm{g}$, which was suitable for the utilization as a precursor in the polyurethane foam preparation. Hse and his coworkers also investigated the production of phenolic compounds from lignin in methanol and some mixture with $\mathrm{H}_{2} \mathrm{SO}_{4}$ as a catalyst (solvent/lignin ratio of $4 / 1, w / w)[50,55,56]$. In comparison with methanol as solvent, the glycerol-methanol mixture could effectively decrease the residue yield from $25 \%$ to $12 \%$. In addition, the amount of phenolics compounds was up to 65.9 in mixed glycerol-methanol at $180{ }^{\circ} \mathrm{C}$ in $15 \mathrm{~min}$. However, the application of $\mathrm{H}_{2} \mathrm{SO}_{4}$ would add to the difficulty for the separation and recycling of catalysts. 
Chen et al. explored the microwave assisted hydrothermal liquefaction of lignin and the application of liquefied products for the preparation of phenolic formaldehyde adhesive [51]. Lignin was extracted from bagasse and was rapidly degraded in hot-compressed water by microwave heating using oxalic acid as a catalyst. They found that the oxalic acid concentration had a significant effect on the reaction rate, and higher oxalic acid concentration could improve the reaction rate. The liquefaction yield reached $78.69 \%$ under the optimal reaction condition $\left(200{ }^{\circ} \mathrm{C}, 30 \mathrm{~min}\right)$, and the liquefaction product was mainly composed of phenolic monomers and oligomers (e.g., 2,6-dimethoxyphenol, 3-hydroxy-4-methoxybenzaldehyde, 4-hydroxybenzaldehyde, etc.) and a few acid-soluble lignin with low molecular weight.

Qiu and Ouyang et al. studied the microwave assisted cleavage of $C_{\alpha}-C_{\beta}$ bonds in several lignin model dimers catalyzed by ferric sulfate or $\mathrm{H}_{2} \mathrm{SO}_{4}$, and found that ferric sulfate was effective for the selective cleavage of $C_{\alpha}-C_{\beta}$ bonds [49,50]. They revealed that ferric sulfate could also lead to the etherification of $C_{\alpha}$-hydroxyl groups in methanol, and thus narrow the distribution of aromatic monomers. Possible conversion routes for selective cleavage of $C_{\alpha}-C_{\beta}$ bonds under microwave heating were proposed for the further study for the depolymerization of lignin.

Xu et al. studied the microwave assisted liquefaction of pine sawdust with $29.25 \mathrm{wt} \%$ lignin using sulfuric acid as catalyst [52]. The liquefaction process was conducted under a relatively mild reaction conditions $\left(700 \mathrm{~W}, 160-185^{\circ} \mathrm{C}\right)$, with almost a negligible amount of gaseous products. The main liquid products detected were phenolic compounds and biopolyols, apart from some solid residues. The highest contents of phenolics and polyhydroxy compounds in the biopolyols were up to $65.9 \%$ and $84.9 \%$, respectively, according to theGas chromatography-mass spectrometry (GC-MS) analysis results.

Kim et al. comparatively investigated the conversion of sulfonated lignin to phenolic chemicals in a conventional batch and a microwave reactor using $\mathrm{KOH}$ as catalyst [53]. In comparison with a conventional batch reactor, phenolic compounds could be controllably produced from lignin in a microwave reactor, with much lower energy cost. During the microwave assisted liquefaction of lignin, guaiacol, vanillin, homovanillic acid, acetovanillone, phenol, and syringol were detected as the main phenolic compounds. The yields of those six products improved, while the reaction temperature increased from 125 to $175^{\circ} \mathrm{C}$. Furthermore, the yields of those main chemicals were highly dependent on the $\mathrm{KOH}$ concentration, confirming the promotional effect of $\mathrm{KOH}$ catalyst.

In general, the separation and recyclability problem of homogeneous catalysts remained a great challenge for the microwave assisted liquefaction of lignin. Thus, heterogeneous catalysts attracted more and more attention for the utilization of lignin sources.

\subsubsection{Heterogeneous Catalyst}

Heterogeneous catalytic lignin liquefaction technologies have received increasing attention and developed rapidly, due to their advantages in achieving high product yields, combined with easier separation and better recyclability of catalysts. Up to now, heterogeneous catalysts used in microwave assisted liquefaction could be generally categorized into three groups: (1) mesoporous Al-SBA-15 based catalysts; (2) microporous HUSY based catalysts; and (3) supported metal catalysts:

\section{(1) Mesoporous Al-SBA-15 based catalysts}

Labidi et al. developed a range of mesoporous Al-SBA-15 supported metal based catalysts, including nickel (loading amount of 2, 5 and $10 \mathrm{wt} \%$ ), palladium ( $2 \mathrm{wt} \%$ ), platinum ( $2 \mathrm{wt} \%$ ) and ruthenium $(2 \mathrm{wt} \%)$, and studied their catalytic performances during the mild microwave assisted depolymerization system [22]. The bio-oil yield improved with the introduction of catalysts into the system, compared to the blank experiment without catalyst, confirming the synergetic effect of metal nanoparticles during the depolymerization process with microwave heating. The highest bio-oil yield was about $17 \%$, while using tetralin as hydrogen donor solvent catalyzed by $10 \% \mathrm{Ni} / \mathrm{Al}-\mathrm{SBA}-15$. In comparison with $\mathrm{Ru}, \mathrm{Pd}$, and Pt based catalysts, Ni-based catalysts could help to depress the repolymerization reaction and decrease the production of biochar during the lignin depolymerization 
process. Luque et al. explored the microwave assisted lignin depolymerization catalyzed by $\mathrm{Ni} / \mathrm{Al}-\mathrm{SBA}-15$ in a mild, hydrogen-free and hydrogenolytic approach promoted by the application of in-situ hydrogen donor solvents [42]. Ni/Al-SBA-15 catalyst could positively contribute to the microwave assisted liquefaction of lignin with tetralin and formic acid as hydrogen-donating solvents. In comparison of those hydrogen donor solvents used in the liquefaction, isopropanol and glycerol exhibited an unappreciable degree of lignin depolymerization. Furthermore, the liquefaction of lignin in formic acid over Ni/Al-SBA-15 could give much higher bio-oil yield with negligible biochar production, while formic acid could decompose into hydrogen and carbon dioxide.

\section{(2) Microporous HUSY based catalysts}

Xiao et al. investigated the catalytic performance of oxalic acid modified HUSY catalyst, finding that HUSY modified with $0.2 \mathrm{~mol} / \mathrm{L}$ oxalic acid could give the highest liquid product yield, due to the improved pore size, acidic sites distribution and $\mathrm{Si} / \mathrm{Al}$ ratio, where the $\mathrm{Si} / \mathrm{Al}$ ratio and the total acidity decreased with increased average pore size from $1.79 \mathrm{~nm}$ to $3.25 \mathrm{~nm}$ [23]. Both the amount of weak and strong acid sites of modified HUSY decreased after oxalic acid treatment. In comparison with raw HUSY, the peak area of weak acid site decreased from 6826 to 1915, and the strong acid site peak area decreased from 12,074 to 3099 , when HUSY was treated with $0.2 \mathrm{M}$ oxalic acid. Furthermore, when the oxalic acid concentration increased to $0.3 \mathrm{M}$, the strong acid peak almost disappeared due to the removal of aluminum, thus the total acidity of modified HUSY further decreased. Xiao et al. indicated the catalyst acidity could not only affect the bio-oil yield, but also influence the product distributions of bio-oil. Apart from the promotion effect in bio-oil yield of catalysts, the addition of HUSY also led to the formation of oligomers in the liquid product, which needed to be further studied to decrease the oligomers content.

\section{(3) Supported metal catalysts}

$\mathrm{Xu}$ et al. prepared CuNiAl hydrotalcite based solid base catalysts, and studied the microwave assisted lignin liquefaction for the production of liquid fuels in methanol [41]. The effect of catalysts, reaction temperature, time, and heating methods were all studied in detail to improve the bio-oil yield. The promotional effect of $\mathrm{Cu}$ amount in the $\mathrm{CuNiAl}$ based catalysts was obviously observed during degradation of lignin, leading to improved bio-oil yield and lower molecular weight. The study could provide a promising technique to convert lignin to liquid fuels over heterogeneous base catalysts. Luque et al. designed a bifunctional catalyst (NiO/H-ZSM-5) combining metal and acid sites, and explored its catalytic activity during the microwave assisted liquefaction of different types of lignin in formic acid under mild reaction conditions [24]. The highest bio-oil yield (about $20 \mathrm{wt} \%$ ) was obtained using $3.5 \mathrm{wt} \% \mathrm{NiO}-\mathrm{H}-\mathrm{ZSM}-5$, using hardwood lignin as the feedstock. The metal composition in catalysts had a great influence on the bio-oil yield, as metal sites were responsible for the cleavage of C-O bond in lignin, while the acidic sites from H-ZSM-5 were responsible for the dealkylation and other deacylation reactions during the lignin depolymerizatin process. The highest bio-oil yield was up to $20 \mathrm{wt} \%$, obtained over $\mathrm{NiO} / \mathrm{H}-\mathrm{ZSM}-5$ with a $\mathrm{NiO}$ content of $3.5 \mathrm{wt} \%$, and the bio-oil yield decreased with the continued increase of $\mathrm{NiO}$ content due to the decrease of surface area, pore diameter in catalysts.

$\mathrm{Li}$ et al. tested a series of carbon nanotube supported rare earth for the catalytic liquefaction of lignin, considering the effect of catalysts, reaction temperature, time on the yield of liquefied fuel [26]. The highest $86.1 \%$ liquefied fuel yield was up to $86.1 \%$ at $260{ }^{\circ} \mathrm{C}$ for $1 \mathrm{~h}$ catalyzed by Ce/CNT. The Ce/CNT catalyst showed good stability after four times reuse, and the liquefied fuel yield stayed at about $82.0 \%$. Furthermore, the calorific value of obtained fuel improved from $24.78 \mathrm{MJ} / \mathrm{kg}$ to $26.13 \mathrm{MJ} / \mathrm{kg}$ compared with raw lignin. Although Ce/CNT could give higher liquid fuel yield, the element analysis results confirmed that liquid fuel obtained from La/CNT showed better quality because of the high content of $\mathrm{C}$ and $\mathrm{H}$ and low content of $\mathrm{O}$. 
In comparison with homogeneous catalysts, heterogeneous catalysts exhibited to be suitable and promising alternatives during the lignin liquefaction system with microwave heating, although some further studies are still in need. Furthermore, the mechanisms for lignin liquefaction under microwave heating in hydrogen donor solvents still need to be further investigated, for the better understanding of the formation of the value-added aromatic compounds.

\section{Conventional Lignin Liquefaction in Hydrogen Donor Solvents}

Lignin liquefaction in hydrogen donor solvents with electric heating has also been extensively studied recently because of the high efficiency for the production of high-yield liquid fuels [57-64]. Hydrogen donor solvents could not only donate hydrogen during the lignin liquefaction process, but also have good solubility of lignin; thus, hydrogen donor solvents, coupled with catalysts, could lead to selective cleavage of C-O and C-C bonds in lignin [57]. Catalysts played an important role during the conventional liquefaction process, which could also be grouped into homogeneous and heterogeneous catalysts. A general summary of researches on the conventional liquefaction of different lignin feedstocks under different reaction conditions was presented in Table 2.

Table 2. Summary of conventional liquefaction of lignin under different reaction conditions.

\begin{tabular}{|c|c|c|c|}
\hline Feedstock & Reaction Conditions & Products & Reference \\
\hline Kraft lignin & $\begin{array}{c}\text { ethanol, } \mathrm{Ru} / \mathrm{C}-\mathrm{MgO} / \mathrm{ZrO}_{2} \\
350{ }^{\circ} \mathrm{C}, 1 \mathrm{~h}, 10 \text { bar N } \\
\end{array}$ & $\begin{array}{l}\text { bio-oil, containing } 17.5 \% \\
\text { phenolic monomer }\end{array}$ & [57] \\
\hline Asian lignin & $\begin{array}{c}\text { ethanol, } \mathrm{Pt} / \mathrm{C}, 350{ }^{\circ} \mathrm{C}, 40 \mathrm{~min}, \\
3 \mathrm{MPa} \mathrm{H} \mathrm{H}_{2}\end{array}$ & $77.4 \%$ of bio-oil, $3.7 \%$ char & [58] \\
\hline organosolv lignin & $\begin{array}{l}\text { ethanol-water, } \mathrm{Ru} / \mathrm{H} \text {-Beta } \\
\text { zeolite, } 225^{\circ} \mathrm{C}, 40 \text { bar } \mathrm{H}_{2}\end{array}$ & $\begin{array}{c}\text { guaiacol, 4-methylguaiacol, } \\
\text { 4-ethylguaiaco, etc. }\end{array}$ & [59] \\
\hline Alcell lignin & $\begin{array}{l}\text { isopropanol-formic acid, } \mathrm{Ru} / \mathrm{C} \text {, } \\
400^{\circ} \mathrm{C}, 4 \mathrm{~h}\end{array}$ & $\begin{array}{l}\text { lignin oils (alkylphenolics, } \\
\text { catechols, guaiacols, etc.) }\end{array}$ & {$[60]$} \\
\hline Kraft lignin & $\begin{array}{l}\text { formic acid, } 10 \% \mathrm{Ni} / \text { Zeolite, } \\
\text { FHUDS-2, } 200-300{ }^{\circ} \mathrm{C}, 1-3 \mathrm{~h}\end{array}$ & $\begin{array}{l}\text { de-polymerized lignin } \\
(1000-3000 \mathrm{~g} / \mathrm{mol})\end{array}$ & [61] \\
\hline Hydrolyzed lignin & $\begin{array}{c}\text { methanol, } \mathrm{Pd} / \mathrm{C} \text { and } \mathrm{CrCl}_{3} \\
300{ }^{\circ} \mathrm{C}, 4 \mathrm{~h}, 2 \mathrm{MPa} \mathrm{H} \mathrm{H}_{2}\end{array}$ & $\begin{array}{l}\text { bio-oil containing } 26.3 \% \\
\text { monomers }\end{array}$ & [62] \\
\hline Organosolv lignin & $\begin{array}{l}\text { isopropanol-water, } \mathrm{Ru} / \mathrm{C} \text { and } \\
\mathrm{NaOH}, 260^{\circ} \mathrm{C}, 1 \mathrm{~h}, 2 \mathrm{MPa} \mathrm{H} \\
\end{array}$ & $95.4 \%$ water-soluble, $6.4 \%$ char & {$[63]$} \\
\hline $\begin{array}{l}\text { Sulfuric acid hydrolysis } \\
\text { lignin, kraft lignin }\end{array}$ & $\begin{array}{c}\mathrm{H}_{2} \mathrm{O} / \text { ethanol, } \mathrm{NaOH} / \mathrm{KOH}, \\
330^{\circ} \mathrm{C}, 30 \mathrm{~min} ; 1 \mathrm{MPa} \mathrm{N}{ }_{2}\end{array}$ & monomer, solid residue & [64] \\
\hline
\end{tabular}

Limarta et al. investigated the catalytic liquefaction of lignin to monophenol-rich bio-oil in supercritical ethanol $\left(350^{\circ} \mathrm{C}, 60 \mathrm{~min}\right)$ over several solid base catalysts, and confirmed that base-catalyzed solvolysis and metal-catalyzed hydrogenolysis both took place during the lignin liquefaction process [57]. The synergic promotional effect of metal and base catalysts was observed, indicating that a combined catalyst of $\mathrm{Ru} / \mathrm{C}$ and $\mathrm{MgO} / \mathrm{ZrO}_{2}$ could help to decrease the molecular weight of bio-oil, improve the yield of phenolic monomers of bio-oil.

Kim et al. explored the catalytic performance of a series of noble metal based catalysts (e.g., $\mathrm{Pt} / \mathrm{C}$, $\mathrm{Pd} / \mathrm{C}, \mathrm{Ru} / \mathrm{C}, \mathrm{Ru} / \mathrm{H}$-Beta zeolite, etc.) in the lignin liquefaction system, with the presence of ethanol [58,59], and confirmed the promotional effect of support. It was reported that the highest yield of phenolic-rich bio-oil from lignin over carbon supported catalysts (e.g., $\mathrm{Pt} / \mathrm{C}, \mathrm{Pd} / \mathrm{C}$ and $\mathrm{Ru} / \mathrm{C}$ ) was up to $77 \%$ in supercritical ethanol, containing $10 \%$ of phenolic monomers [58]. Additionally, the synergic effect of noble metal and solid acid was observed in $\mathrm{Ru} / \mathrm{H}$-Beta zeolite catalyst, as the yield of phenolic monomers improved to $16.5 \%$ with decreased molecular weight of liquid products [56]. Kloekhorst et al. also studied the reductive liquefaction of lignin over $\mathrm{Ru} / \mathrm{C}$ using mixed 2-propanol/formic acid (mass 
ratio of $1: 1,400{ }^{\circ} \mathrm{C}$ ) as hydrogen donor solvent [60]. The obtained bio-oil yield was up to $71 \%$, with a much higher phenolic monomer yield of $21.7 \%$.

$\mathrm{Xu}$ et al. comparatively explored the catalytic performances of several Ni-based catalysts and $\mathrm{Ru}$-based catalysts $(\mathrm{Ru} / \mathrm{C})$ during the liquefaction of kraft lignin in ethanol-water mixture $(v / v$ of 1:1) with formic acid as a source of in situ hydrogen [61]. They found that the molecular weight of depolymerized liquid products decreased obviously with the presence of each supported metal catalysts. Among all the catalysts, two kinds of Ni-based catalysts (e.g., FHUDS-2 and Ni/Zeolite) were much more suitable for sulfur-removal, and exhibited to be more effective than Ru-based catalysts $(\mathrm{Ru} / \mathrm{C})$ for the lignin liquefaction. The liquefied products had a total hydroxyl number of $347-466 \mathrm{mg}$ $\mathrm{KOH} / \mathrm{g}$ and an aliphatic hydroxyl number of 139-326 mg KOH/g, greater than that of the original lignin (275 mg KOH/g total hydroxyl number and $128 \mathrm{mg} \mathrm{KOH} / \mathrm{g}$ aliphatic hydroxyl number), which could be used as a bio-replacement for petroleum-based polyols or phenol for the production of bio-based foams or resins.

$\mathrm{Xu}$ et al. investigated the conversion of concentrated sulfuric acid hydrolyzed lignin to value-added monomers catalyzed by $\mathrm{Pd} / \mathrm{C}$ coupled with $\mathrm{CrCl}_{3}$ [62]. Different types of solvents, reaction temperature and time were studied in detail to understand their influences on the lignin liquefaction process. It was found that supercritical methanol exhibited the best depolymerization performance, due to the better diffusion, dissolution and much more suitable acid-base properties. The highest monomer yield was up to $26.3 \%$ over $\mathrm{Pd} / \mathrm{C}$ coupled with $\mathrm{CrCl}_{3}$ in supercritical methanol under the optimal reaction conditions $\left(300^{\circ} \mathrm{C}, 4 \mathrm{~h}\right)$, with the extra addition of hydrogen. They also found that higher reaction temperature would improve the lignin liquefaction, as the $\beta-\mathrm{O}-4$ linkages cleaved significantly in lignin. Simultaneously, some side reactions, such as repolymerizaton, were also preferred at higher temperature, leading to the increase of coke and char amount, which needed to be depressed in future studies.

Sun et al. established a synergetic catalytic system for the depolymerization of organosolv lignin and in situ hydrogenolysis under mild conditions using $\mathrm{NaOH}$ and some noble metal catalysts $(\mathrm{Ru} / \mathrm{C}$, $\mathrm{Pt} / \mathrm{C}$, and $\mathrm{Pd} / \mathrm{C}$ ), which was also effective for char elimination [63]. They found that those ether bonds in lignin were supposed to cleave firstly to produce unstable oligomers. Then, those oligomers would convert into much more stable monomers during the base-catalyzed liquefaction in hydrogen donor solvent (e.g., isopropanol). The highest yield of water-soluble fraction (95.4\%) was obtained under the optimal conditions $\left(260^{\circ} \mathrm{C}, 0.025 \mathrm{~mol} \mathrm{NaOH}\right.$ and $\left.5 \% \mathrm{Ru} / \mathrm{C}\right)$, and the products contained $24.3 \%$ degraded lignin, $44.6 \%$ water-soluble products and $26.5 \%$ oil-soluble products. Furthermore, the liquefied products were quite suitable for producing lignin-based flame resistant material because of its excellent thermal stability.

Kim et al. investigated the base-catalyzed depolymerization of lignin to value-added aromatic monomers in sub- and supercritical solvents [64]. They studied the effects of lignin feedstocks (concentrated sulfuric acid hydrolysis lignin and kraft lignin), base catalysts $(\mathrm{NaOH}, \mathrm{KOH}$, and $\mathrm{Na}_{2} \mathrm{CO}_{3}$ ) and solvents (subcritical water and supercritical methanol)on the lignin liquefaction and product distributions (gas, bio-oil, solid residue, and aromatic monomers). They reported that aromatic monomeric yields of $17.2 \%$ and $20.4 \%$ were achieved from concentrated sulfuric acid hydrolysis lignin and kraft lignin, in an aqueous $\mathrm{NaOH}$ or $\mathrm{KOH}$ solution with a relatively lower concentrations $(0.5 \mathrm{wt} \%)$. The structure of monomers in bio-oil was closely associated with the solvent, as catechols and alkylated and alkoxylated derivatives were the main monomers in subcritical water, and methoxylated benzene and toluene species were mostly observed in supercritical methanol because of its unique O-alkylation ability.

It could be concluded that both conventional and microwave assisted liquefaction in hydrogen donor solvents were effective for the lignin valorization. However, microwave assisted technologies seemed to be much more energy-saving, and more promising for the conversion of lignin to value-added products. 


\section{Conclusions}

The integration of microwave technology and catalytic solvolysis provides a promising approach for the value-added utilization of lignin, as it could not only reduce the utilization cost, but also make the large-scale conversion of lignin feasible. Thus, microwave assisted liquefaction of lignin in hydrogen donor solvents exhibits to be an alternative method for the conversion of lignin to value-added products. As many effective microwave assisted lignin liquefaction systems have been reported in recent years, it is foreseeable that the mild reaction conditions could be achieved with the presence of suitable hydrogen donor solvents and catalysts, with the help of microwave technology. Although microwave assisted lignin liquefaction has attracted increasing attention, some issues still need to be further investigated: (1) preparation heterogeneous catalysts with high catalytic activity and good stability; (2) identification of oligomer structures for the better understanding of lignin depolymerization pathways; and (3) improvement of phenolic monomers selectivity towards value-added fine chemicals. If all of the above issues could be successfully addressed, the microwave assisted lignin liquefaction technology could improve the commercial and large-scale utilization and economic outlook of abundant lignin sources.

Author Contributions: J.X. and J.J. contribute to the writing of introduction and the section of conventional lignin liquefaction; M.Z. and B.K.S. contribute to the writing of the microwave assisted lignin liquefaction, and are responsible for the English expression of the manuscript.

Acknowledgments: Authors are grateful for financial support from Fundamental Research Funds of Chinese Academy of Forestry (CAF) (No. CAFYBB2018QB007), the National Natural Science Foundation of China (31700645), and the Natural Science Foundation of Jiangsu Province (BK20170159). Minghao Zhou (201703270013) would like to acknowledge the fellowship from the China Scholarship Council (CSC).

Conflicts of Interest: The authors declare no conflicts of interest.

\section{References}

1. Li, C.; Zhao, X.; Wang, A.; Huber, G.W.; Zhang, T. Catalytic transformation of lignin for the production of chemicals and fuels. Chem. Rev. 2015, 115, 11559-11624. [CrossRef] [PubMed]

2. Rinaldi, R.; Jastrzebski, R.; Clough, M.T.; Ralph, J.; Kennema, M.; Bruijnincx, P.C.; Weckhuysen, B.M. Paving the way for lignin valorisation: Recent advances in bioengineering, biorefining and catalysis. Angew. Chem. Int. Ed. 2016, 55, 8164-8215. [CrossRef] [PubMed]

3. Ho, D.P.; Ngo, H.H.; Guo, W. A mini review on renewable sources for biofuel. Bioresour. Technol. 2014, 169, 742-749. [CrossRef] [PubMed]

4. Serrano-Ruiz, J.C.; Luque, R.; Sepulveda-Escribanoa, A. Transformations of biomass-derived platform molecules: From high added-value chemicals to fuels via aqueous-phase processing. Chem. Soc. Rev. 2011, 40, 5266-5281. [CrossRef] [PubMed]

5. Rinaldi, R.; Palkovits, R.; Schuth, F. Depolymerization of cellulose using solid catalysts in ionic liquids. Angew. Chem. Int. Ed. 2008, 47, 8047-8050. [CrossRef] [PubMed]

6. Gosselink, R.J.A.; de Jong, E.; Guran, B.; Abacherli, A. Co-ordination network for lignin-standardisation, production and applications adapted to market requirements. Ind. Crops Prod. 2004, 20, 121-129. [CrossRef]

7. Fan, L.L.; Zhang, Y.N.; Liu, S.Y.; Zhou, N.; Chen, P.; Cheng, Y.L.; Addy, M.; Lu, Q.; Omar, M.M.; Liu, Y.H.; et al. Bio-oil from fast pyrolysis of lignin: Effects of process and upgrading parameters. Bioresour. Technol. 2017, 241, 1118-1126. [CrossRef] [PubMed]

8. Effendi, A.; Gerhauser, H.; Bridgwater, A.V. Production of renewable phenolic resins by thermochemical conversion of biomass: A review. Renew. Sustain. Energy Rev. 2008, 12, 2092-2116. [CrossRef]

9. Wen, J.L.; Xue, B.L.; Xu, F.; Sun, R.C.; Pinkert, A. Unmasking the structural features and property of lignin from bamboo. Ind. Crops Prod. 2013, 42, 332-343. [CrossRef]

10. Ragauskas, A.J.; Beckham, G.T.; Biddy, M.J.; Chandra, R.; Chen, F.; Davis, M.F.; Avison, B.H.; Dixon, R.A.; Gilna, P.; Keller, M. Lignin valorization: Improving lignin processing in the biorefinery. Science 2014, 344, 709-721. [CrossRef] [PubMed]

11. Hu, L.H.; Pan, H.; Zhou, Y.H.; Zhang, M. Methods to improve lignin's reactivity as a phenol substitute and as replacement for other phenolic compounds: A brief review. BioResources 2011, 6, 3515-3525. 
12. Naik, S.N.; Goud, V.V.; Rout, P.K.; Dalai, A.K. Production of first and second generation biofuels: A comprehensive review. Renew. Sustain. Energy Rev. 2010, 14, 578-597. [CrossRef]

13. Calvo-Flores, F.G.; Dobado, J.A. Lignin as renewable raw material. ChemSusChem 2010, 3, 1227-1235. [CrossRef] [PubMed]

14. Carpenter, D.; Westover, T.L.; Czernik, S.; Jablonski, W. Biomass feedstocks for renewable fuel production: A review of the impacts of feedstock and pretreatment on the yield and product distribution of fast pyrolysis bio-oils and vapors. Green Chem. 2014, 16, 384-406. [CrossRef]

15. Li, H.; Qu, Y.; Xu, J. Microwave-assisted conversion of lignin. In Production of Biofuels and Chemicals with Microwave; Zhen, F., Richard, L.S., Jr., Qi, X.H., Eds.; Springer: Dordrecht, The Netherlands, 2015; Volume 3, pp. 61-82, ISBN 978-94-017-9611-8.

16. Shen, D.; Jin, W.; Hu, J.; Xiao, R.; Luo, K. An overview on fast pyrolysis of the main constituents in lignocellulosic biomass to valued-added chemicals: Structures, pathways and interactions. Renew. Sustain. Energy Rev. 2015, 51, 761-774. [CrossRef]

17. Azadi, P.; Inderwildi, O.R.; Farnood, R.; King, D.A. Liquid fuels, hydrogen and chemicals from lignin: A critical review. Renew. Sustain. Energy Rev. 2013, 21, 506-523. [CrossRef]

18. Kang, S.; Li, X.; Fan, J.; Chang, J. Hydrothermal conversion of lignin: A review. Renew. Sustain. Energy Rev. 2013, 27, 546-558. [CrossRef]

19. Duan, D.L.; Wang, Y.P.; Ruan, R.; Tayier, M.; Dai, L.L.; Zhao, Y.F.; Zhou, Y.; Liu, Y.H. Comparative study on various alcohols solvolysis of organosolv lignin using microwave energy: Physicochemical and morphological properties. Chem. Eng. Process. 2018, 126, 38-44. [CrossRef]

20. Tayier, M.; Duan, D.L.; Zhao, Y.F.; Ruan, R.; Wang, Y.P.; Liu, Y.H. Catalytic effects of various acids on microwave assisted depolymerization of organosolv lignin. Bioresource 2018, 13, 412-424. [CrossRef]

21. Zou, R.; Zhao, Y.F.; Wang, Y.P.; Duan, D.L.; Fan, L.L.; Dai, L.L.; Liu, Y.H.; Ruan, R.S. Microwave-assisted depolymerization of lignin with metal chloride in a hydrochloric acid and formic acid system. Bioresource 2018, 13, 3704-3719. [CrossRef]

22. Toledano, A.; Serrano, L.; Pineda, A.; Romero, A.A.; Luque, R.; Labidi, J. Microwave-assisted depolymerisation of organosolv lignin via mild hydrogen-free hydrogenolysis: Catalyst screening. Appl. Catal. B: Environ. 2014, 145, 43-55. [CrossRef]

23. Shen, D.K.; Liu, N.N.; Dong, C.J.; Xiao, R.; Gu, S. Catalytic solvolysis of lignin with the modified HUSYs in formic acid assisted by microwave heating. Chem. Eng. J. 2015, 270, 641-647. [CrossRef]

24. Milovanovic, J.; Rajic, N.; Romero, A.A.; Li, H.K.; Shih, K.; Tschentscher, R.; Luque, R. Insights into the microwave-assisted mild deconstruction of lignin feedstocks using NiO-containing ZSM-5 zeolites. ACS Sustain. Chem. Eng. 2016, 4, 4305-4313. [CrossRef]

25. Xiao, W.; Han, L.; Zhao, Y. Comparative study of conventional and microwave-assisted liquefaction of corn stover in ethylene glycol. Ind. Crops Prod. 2011, 34, 1602-1606. [CrossRef]

26. Ma, Q.Z.; Liu, Q.Y.; Li, W.Z.; Ma, L.L.; Wang, J.D.; Liu, M.H.; Zhang, Q. Catalytic depolymerization of lignin for liquefied fuel at mild condition by rare earth metals loading on CNT. Fuel Process. Technol. 2017, 161, 220-225. [CrossRef]

27. Salema, A.A.; Ani, F.N. Microwave induced pyrolysis of oil palm biomass. Bioresour. Technol. 2011, 102, 3388-3395. [CrossRef] [PubMed]

28. Shu, R.Y.; Long, J.X.; Xu, Y.; Ma, L.L.; Zhang, Q.; Wang, T.J.; Wang, C.G.; Yuan, Z.Q.; Wu, Q.Y. Investigation on the structural effect of lignin during the hydrogenolysis process. Bioresour. Technol. 2016, 200, 14-22. [CrossRef] [PubMed]

29. Guo, J.; Zhuang, Y.; Chen, L.; Liu, J.; Li, D.; Ye, N. Process optimization for microwave assisted direct liquefaction of Sargassum polycystum, C. agardh using response surface methodology. Bioresour. Technol. 2012, 120, 19-25. [CrossRef] [PubMed]

30. Liu, J.B.; Zhuang, Y.B.; Li, Y.; Chen, L.M.; Guo, J.X.; Li, D.M.; Ye, N.H. Optimizing the conditions for the microwave-assisted direct liquefaction of Ulva prolifera for bio-oil production using response surface methodology. Energy 2013, 60, 69-76. [CrossRef]

31. Podschun, J.; Saake, B.; Lehnen, R. Catalytic demethylation of organosolv lignin in aqueous medium using indium triflate under microwave irradiation. React. Funct. Polym. 2017, 119, 82-86. [CrossRef] 
32. Zhou, L.; Budarin, V.; Fan, J.J.; Sloan, R.; Macquarrie, D. Efficient method of lignin isolation using microwave-assisted acidolysis and characterization of the residual lignin. ACS Sustain. Chem. Eng. 2017, 5, 3768-3774. [CrossRef]

33. Bundhoo, Z.M.A. Microwave-assisted conversion of biomass and waste materials to biofuels. Renew. Sustain. Energy Rev. 2018, 82, 1149-1177. [CrossRef]

34. Xu, C.; Arancon, R.A.D.; Labidid, J.; Luque, R. Lignin depolymerisation strategies-Towards valuable chemicals and fuels. Chem. Soc. Rev. 2014, 43, 7485-7500. [CrossRef] [PubMed]

35. Stewart, D. Lignin as a base material for materials applications: Chemistry, application and economics. Ind. Crops Prod. 2008, 27, 202-207. [CrossRef]

36. Zakzeski, J.; Bruijnincx, P.C.A.; Jongerius, A.L.; Weckhuysen, B.M. The catalytic valorization of lignin for the production of renewable chemicals. Chem. Rev. 2010, 110, 3552-3599. [CrossRef] [PubMed]

37. Chen, C.B.; Wang, J.Z.; Shen, D.K.; Xue, J.T.; Guan, S.P.; Gu, S.; Luo, K.H. Catalytic oxidation of lignin in solvent systems for production of renewable chemicals: A review. Polymers 2017, 9, 240. [CrossRef]

38. Lange, H.; Decina, S.; Crestini, C. Oxidative upgrade of lignin-Recent routes reviewed. Eur. Polym. J. 2013, 49, 1151-1173. [CrossRef]

39. Behling, R.; Valange, S.; Chatel, G. Heterogeneous catalytic oxidation for lignin valorization into valuable chemicals: What results? What limitations? What trends? Green Chem. 2016, 18, 1839-1854. [CrossRef]

40. Bu, Q.; Lei, H.; Ren, S.; Wang, L.; Zhang, Q.; Tang, J.; Ruan, R. Production of phenols and biofuels by catalytic microwave pyrolysis of lignocellulosic biomass. Bioresour. Technol. 2012, 108, 274-279. [CrossRef] [PubMed]

41. Zhou, M.H.; Sharma, B.K.; Liu, P.; Xia, H.H.; Xu, J.M.; Jiang, J.C. Microwave assisted depolymerization of alkaline lignin over hydrotalcite-based CuNiAl mixed oxides. ACS Sustain. Chem. Eng. 2018, 6, 11519-11528. [CrossRef]

42. Toledano, A.; Serrano, L.; Labidi, J.; Pineda, A.; Balu, A.M.; Luque, R. Heterogeneously catalysed mild hydrogenolytic depolymerisation of lignin under microwave irradiation with hydrogen-donating solvents. ChemCatChem 2013, 5, 977-985. [CrossRef]

43. Liu, Q.; Li, P.F.; Liu, N.N.; Shen, D.K. Lignin depolymerization to aromatic monomers and oligomers in isopropanol assisted by microwave heating. Polym. Degrad. Stabil. 2017, 135, 54-60. [CrossRef]

44. Dhar, P.; Vinu, R. Understanding lignin depolymerization to phenols via microwave-assisted solvolysis process. J. Environ. Chem. Eng. 2017, 5, 4759-4768. [CrossRef]

45. Shao, L.P.; Zhang, Q.L.; You, T.T.; Zhang, X.M.; Xu, F. Microwave-assisted efficient depolymerization of alkaline lignin in methanol/formic acid media. Bioresour. Technol. 2018, 264, 238-243. [CrossRef] [PubMed]

46. Ouyang, X.P.; Zhu, G.D.; Huang, X.Z.; Qiu, X.Q. Microwave assisted liquefaction of wheat straw alkali lignin for the production of monophenolic compounds. J. Energy Chem. 2015, 24, 72-76. [CrossRef]

47. Duan, D.L.; Zhao, Y.F.; Fan, L.L.; Dai, L.L.; Lv, J.Q.; Ruan, R.; Wang, Y.P.; Liu, Y.H. Low-power microwave radiation-assisted depolymerization of ethanol organsolv lignin in ethanol/formic acid mixtures. Bioresources 2017, 12, 5308-5320. [CrossRef]

48. Gosz, K.; Kosmela, P.; Hejna, A.; Gajowiec, G.; Piszczyk, L. Biopolyols obtained via microwave-assisted liquefaction of lignin: Structure, rheological, physical and thermal properties. Wood Sci. Technol. 2018, 52, 599-617. [CrossRef]

49. Zhu, G.D.; Lin, M.L.; Fan, D.; Ning, W.S.; Ouyang, X.P.; Qian, Y.; Qiu, X.Q. Effect of benzyl functionality on microwave-assisted cleavage of $\mathrm{C}_{\alpha}-\mathrm{C}_{\beta}$ bonds in lignin model compounds. J. Phys. Chem. C 2017, 121, 1537-1545. [CrossRef]

50. Zhu, G.D.; Jin, D.X.; Zhao, L.S.; Ouyang, X.P.; Chen, C.; Qiu, X.Q. Microwave-assisted selective cleavage of $\mathrm{C}_{\alpha}-\mathrm{C}_{\beta}$ bond for lignin depolymerization. Fuel Process. Technol. 2017, 161, 155-161. [CrossRef]

51. Li, Y.M.; Li, B.Z.; Du, F.L.; Wang, Y.; Pan, L.X.; Chen, D. Microwave-assisted hydrothermal liquefaction of lignin for the preparation of phenolic formaldehyde adhesive. J. Appl. Polym. Sci. 2017, 134, 44510-44517. [CrossRef]

52. Xu, J.; Jiang, J.; Hse, C.; Shupe, T.F. Renewable chemical feedstocks from integrated liquefaction processing of lignocellulosic materials using microwave energy. Green Chem. 2012, 14, 2821-2830. [CrossRef]

53. Kim, H.G.; Park, Y. Manageable conversion of lignin to phenolic chemicals using a microwave reactor in the presence of potassium hydroxide. Ind. Eng. Chem. Res. 2013, 52, 10059-10062. [CrossRef]

54. Sequeiros, A.; Serrano, L.; Briones, R.; Labidi, J. Lignin liquefaction under microwave heating. J. Appl. Polym. Sci. 2013, 130, 3292-3298. [CrossRef] 
55. Xie, J.L.; Qi, J.Q.; Hse, C.Y.; Shupe, T.F. Effect of lignin derivatives in the bio-polyols from microwave liquefied bamboo on the properties of polyurethane foams. Bioresources 2014, 9, 578-588. [CrossRef]

56. Huang, X.Y.; De Hoop, C.F.; Xie, J.L.; Hse, C.Y.; Qi, J.Q.; Hu, T.X. Characterization of biobased polyurethane foams employing lignin fractionated from microwave liquefied switchgrass. Int. J. Polym. Sci. 2017. [CrossRef]

57. Limarta, S.O.; Ha, J.M.; Park, Y.K.; Lee, H.; Suh, D.J.; Jae, J. Efficient depolymerization of lignin in supercritical ethanol by a combination of metal and base catalysts. J. Ind. Eng. Chem. 2018, 57, 45-54. [CrossRef]

58. Kim, J.Y.; Park, J.; Kim, U.J.; Choi, J.W. Conversion of lignin to phenol-rich oil fraction under supercritical alcohols in the presence of metal catalysts. Energy Fuels 2015, 29, 5154-5163. [CrossRef]

59. Kim, M.; Son, D.; Choi, J.W.; Jae, J.; Suh, D.J.; Ha, J.M.; Lee, K.Y. Production of phenolic hydrocarbons using catalytic depolymerization of empty fruit bunch (EFB)-derived organosolv lignin on H beta-supported Ru. Chem. Eng. J. 2017, 309, 187-196. [CrossRef]

60. Kloekhorst, A.; Shen, Y.; Yie, Y.; Fang, M.; Heeres, H.J. Catalytic hydrodeoxygenation and hydrocracking of Alcell (R) lignin in alcohol/formic acid mixtures using a Ru/C catalyst. Biomass Bioenergy 2015, 80, 147-161. [CrossRef]

61. Huang, S.H.; Mahmood, N.; Zhang, Y.S.; Tymchyshyn, M.; Yuan, Z.S.; Xu, C. Reductive de-polymerization of kraft lignin with formic acid at low temperatures using inexpensive supported Ni-based catalysts. Fuel 2017, 209, 579-586. [CrossRef]

62. Shu, R.Y.; Zhang, Q.; Ma, L.L.; Xu, Y.; Chen, P.R.; Wang, C.G.; Wang, T.J. Insight into the solvent, temperature and time effects on the hydrogenolysis of hydrolyzed lignin. Bioresour. Technol. 2016, 221, 568-575. [CrossRef] [PubMed]

63. Shen, X.J.; Huang, P.L.; Wen, J.L.; Sun, R.C. A facile method for char elimination during base-catalyzed depolymerization and hydrogenolysis of lignin. Fuel Process. Technol. 2017, 167, 491-501. [CrossRef]

64. Hidajat, M.J.; Riaz, A.; Park, J.; Insyani, R.; Verma, D.; Kim, J. Depolymerization of concentrated sulfuric acid hydrolysis lignin to high-yield aromatic monomers in basic sub- and supercritical fluids. Chem. Eng. J. 2017, 317, 9-19. [CrossRef] 